\title{
SUPERCAPACITORS AND ITS ENACTMENT FOR RENEWABLE ENERGY RESOURCES
}

Tanzila Younas

Department of Mechatronics Engineering, SZABIST. Karachi, (Pakistan).

E-mail: tanzila@szabist.edu.pk

ORCID: https://orcid.org/0000-0001-7571-1921

Khawaja Moez Ur Rehman

Department of Mechatronics Engineering, SZABIST. Karachi, (Pakistan).

E-mail: khawajamoez07@outlook.com

ORCID: https://orcid.org/0000-0003-2974-4436

Muhammad Taha Khan

Department of Mechatronics Engineering, SZABIST. Karachi, (Pakistan).

E-mail: tahatariq64@outlook.com

ORCID: https://orcid.org/0000-0003-3843-8174

Taimoor Inayat

Department of Mechatronics Engineering, SZABIST. Karachi, (Pakistan).

E-mail: taimoorinayat66@gmail.com

ORCID: https://orcid.org/0000-0002-8410-4696

Recepción: 01/09/2021 Aceptación: 27/10/2021 Publicación: 14/02/2022

\section{Citación sugerida:}

Younas, T., Ur, K. M., Khan, M. T., y Inayat, T. (2022). Supercapacitors and Its Enactment for Renewable Energy Resources. 3C Tecnología. Glosas de innovación aplicadas a la pyme, Edición Especial, (febrero 2022), 65-95. https://doi.org/10.17993/3ctecno.2022.specialissue9.65-95 


\section{ABSTRACT}

Storing energy has been one of the major issues faced around the globe. Storage of energy, through using batteries from renewable energy is not sufficient, as it has lower power density and low life expectancy. However, in the modern as well as in coming future, supercapacitors, are and will be capable of replacing batteries for energy storage purposes and for short term charge/discharge cycles. Super Capacitor (SG) is a double layered capacitor having higher capacitance with higher power density and higher energy density than normal capacitor and battery. Preceding study on the stated purpose relied on batteries and on coupling the batteries since higher density power capacitor was not invented. This study, examines the use of supercapacitors as an energy storage device for renewable energy sources such as "wind energy" and "photovoltaic (solar)." The latest advancement in this field is the invention of activated carbon from biomass for the electrodes for $\mathrm{SC}$ applications. This paper provides the insight about the SC technology with reference to carbon and carbon-based materials derived from biodegradable waste. In addition to this, it also provides comparison between the storage mechanisms of the bio-electrodes.

\section{KEYWORDS}

Stabilization, Wind energy, Pitch control, Bio-electrodes, Supercapacitor, Energy density, Photovoltaic (PV). 


\section{INTRODUCTION}

With the continuous rapid growth in the economy, there is an increasing demand in energy and the quality of power. The persistent decay of the worldwide climate and the consistent exhaustion of fossil fuel energy, economical energy sources, for example, wind and photovoltaic energy have been given impressive regard due to its contamination free and reusing points of interest. These renewable energy resources become alluring arrangements to satisfy the vitality and the power quality necessity. However, SC's not only just stores the abundant power flexibly into the electrical hardware at night or in clear events, it improves the force nature of the sustainable power age organization, or fills in as a reinforcement power gracefully for the quick force to uphold (Billinton, 2005). Many wind turbines produce a lot of their energy around evening time when winds are higher and solar plants produce power dependent on sunshine varieties. The capacity is one of the whacking problems in the utilization of sustainable power assets such as wind turbine energy and photovoltaic (solar) energy. The potential to store energy when it is delivered is a basic waypoint towards transforming elective energy into normal energy ("Supercapacitors: Making Renewable Energy Viable," 2011).

The sustainable power age requires its energy capacity parts to take a swift reaction trademark, high unwavering quality and adaptable energy on the board. Therefore, many storage modules have been used like flywheels, lead-acid batteries, capacitors and Supercapacitors. Flywheels can be financially feasible at higher force levels, however, having said that, they are truly huge and one must consider various wellbeing and upkeep issues associated with their establishment. Batteries have significant improvement and substitution issues, and observing their condition of charge, is consistently troublesome (Schainker, 2004). Capacitors take too much time in charge and discharge cycle unlike batteries. They cannot store more than batteries whereas batteries store thousands of times more energy than them. In most cases, capacitors are not environmentally friendly as their life span is very less. On the other hand, supercapacitors replacing all of the above storage devices are faster, reliable and however durable. Analysis of lead acid batteries, capacitors and supercapacitors is shown in Figure 1. 
The absorption of electrolyte particles onto the exterior of anode materials is employed to hold charge in supercapacitors, also known as double-layered capacitors (Simon et al., 2014). As another element they can give an elite and profitable arrangement a moderate force level, because of its focal points, for example, high charge/release current capacity, high productivity and wide temperature range (Burke, 2000).

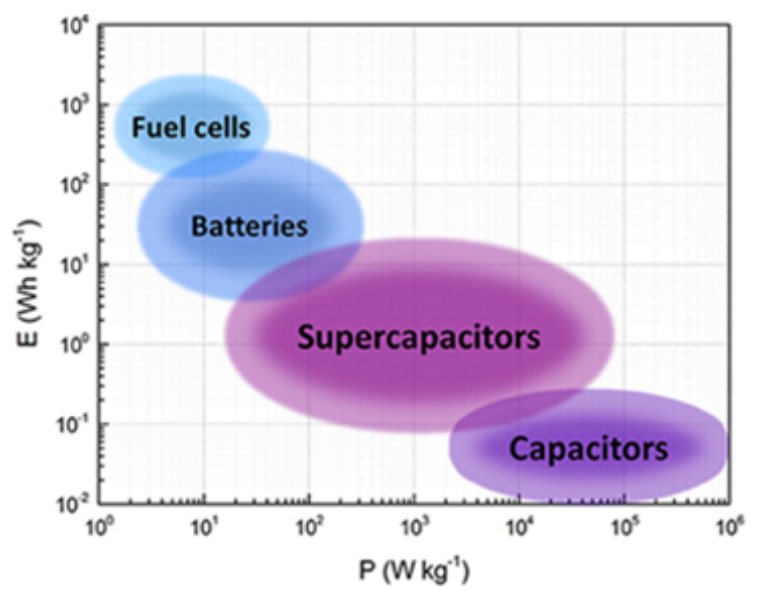

Graphic 1. Ragone plot showing the typical values of energy and power of different energy storage devices.

Source: (Castro-Gutiérrez et al., 2020).

Supercapacitors end up being better than occupant battery frameworks, performing long ways past the batteries' constraints. Supercapacitors provide lower voltage limits which creates a gap between lithium-ion batteries and electrolytic capacitors. SC's are utilized in various sectors including automotive industry, renewable energy resources, and hybrid transport and so on. In hybrid power systems SC's are being used with batteries for better achievement of mechanism working and it also reclaims energy through restoration of the breaking system in the vehicle. In sustainable energy sources, they play a vital role in wind thermal energy and photovoltaic energy.

Green supercapacitor (SC) technology is the voice of the new techno-world. Materials derived from bio-products and bio-wastes, have attained a high popularity. In this paper, formation of electrodes for SC from various green sources is discussed and compared. This paper provides deep insight about the performance of porous/activated bio-carbon electrodes. 


\section{MATERIALS AND METHODS}

\subsection{ULTRACAPACITORS IN RENEWABLE ENERGY RESOURCES}

\subsubsection{WIND ENERGY}

Wind power is one of the quickest developing inexhaustible force age innovations. Nonetheless, wind energy is one of most flighty fuel sources, since it relies upon variable wind speed. An adjustment in wind speed influences the force nature of the lattice since it produces vacillations in the turbines yield power. In recent times, wind turbines highlighted straightforwardly movable rotors to dispense with the dynamic force vacillation. This smooths the force yield; however, it offers restricted abilities to change power. The framework of the receptive force variance is eliminated by utilizing power remuneration gadgets. Having stated that, the dynamic force vacillations can't be settled by utilizing power pay gadgets. The voltage transport of wind homesteads can be settled by utilizing energy stockpiling hardware. It is additionally conceivable to change the dynamic and receptive force by adding a capacity gadget. Research shows that the force nature of the framework is significantly influenced by the fluctuating force at 0.01 to $1 \mathrm{~Hz}$. The forcing nature of the network is enormously influenced by the power fluctuation in this recurrence band. A momentary stockpiling gadget can be utilized to stifle the change of wind power in this recurrence band. However, according to its capacity, a gadget which is fit for understanding its energy in a short timespan has numerous applications in wind power framework. Supercapacitors can be utilized in wind power frameworks to address high current vacillations. It will be highly considerable because of their high current charge and release properties. The long existence of supercapacitors, likewise makes them an ideal usage of wind power. Energy will be released/generated in a way in the supercapacitor when the wind is solid. At a point when the wind speed changes, the supercapacitor will start to release and streamlining the framework's yield power, empowering a more productive matrix framework (Haider, 2020).

\subsubsection{PITCH CONTROL OF TURBINE BLADES}

Pitch control is the innovation used to work and control the position of the blades in a wind turbine. Wind turbine pitch control is one key approach that is significant from both the purposes of wellbeing and effectiveness, and acts additionally where SC's are picking 
up foothold (Pikkarainen, n.d.). An unmanageable blade pitch can swiftly transform into calamitous collapse. Electric pitch control systems, hydraulic pitch control systems, battery pitch control systems, and supercapacitor pitch control systems are the four types of pitch control systems. We will discuss the SC based pitch control system in the paper. SC's are the principal pitch innovation utilized for turbines today, taking the main offer situation of $43 \%$ in recently introduced turbines around the world.

The innovation of SC is known for its uncommon capacity to fuel a high flood of intensity in contrast to batteries, supercapacitors can catch and deliver rapid productive energy. An ultra-capacitor stores energy in an electric field, as opposed to in a compound response, so it endures many thousands more in charge and release cycles than a battery. Ultracapacitors work in much lower and higher temperatures, since they don't contain synthetics that are defenseless to ecological conditions. These characteristics have made them alluring, particularly for hard-to-get to seaward turbines which work in incredibly hot temperatures. SC's are a basic dependability part of the turbine pitch control framework, dealing with the pitch for every sharp edge separately and performing basic capacities by "feathering" the blades to improve the effectiveness of wind energy change, just as closing down the framework by contributing the edges to zero the instance of high winds or a network disappointment for safeguard activity (Dvorak, 2016).

A pitch framework render offers the upside of killing steady battery voltage flaws, and untimely battery framework disappointments. Battery voltage blames regularly show up when a turbine reboots itself after a utility lattice power disappointment, or when there is a battery charger disappointment, or when the battery doesn't charge in cool climate conditions. In the event, the shortcoming can't be settled distantly, so a professional should climb the turbine to survey the issue which results in consistent extra support, and misfortune income and the turbine stays out of activity. Untimely battery framework disappointments are additionally normal, generally when the battery framework works in outrageous cold temperatures.

High temperatures additionally influence battery execution and can add to battery corruption after some time. Changing the encompassing natural conditions makes it harder to foresee the battery framework operational lifetime. Restoring battery frameworks, 
which is regulatory essential each four to five years and regularly inside one to two years, is an expensive cycle that requires more support, successive vacation to supplant batteries or beware of battery shortcomings, and an expanded number of turbine climbs, which builds danger to upkeep staff. Therefore, many wind farms have replaced battery systems over ultracapacitor based systems as they work authentically for at least 10 years or more. SC's fundamentally diminish the expense of reinforcement parts and distribution center endeavors, turbine climbs, and removal endeavors (Werkstetter, 2015).

\subsubsection{SOLAR POWER ENERGY}

Solar power energy is a sustainable free source of energy, which is feasible and absolutely endless, not at all like oil-based products that are restricted. It is moreover, a non-dirtying wellspring of energy and it doesn't transmit any ozone harming substances while delivering power (Younas et al., 2018). The variable contribution of the solar PV cells frequently adversely influences battery life. PV cell creation relies upon the climatic conditions, making them truly unstable and shaky. Battery life is seriously harmed by these yield changes, which interferes with the battery charging and releasing cycle.

In a solar PV framework, the hybrid energy storage system is planned by joining a supercapacitor with a battery to expand the energy thickness of the framework. This framework has a larger number of focal points than the individual utilization of a SC or battery. The weight on batteries can be decreased by utilizing a half breed arrangement of SC's and batteries. The working and upkeep cost of the new framework will be less in light of the fact which diminishes the size and pace of release of the battery and subsequently builds the battery life. This crossbreed stockpiling framework will likewise improve the force quality of a solar PV system (Haider, 2020). A model of solar PV system consisting of SC combined with batteries is shown in the Figure 4 below. 


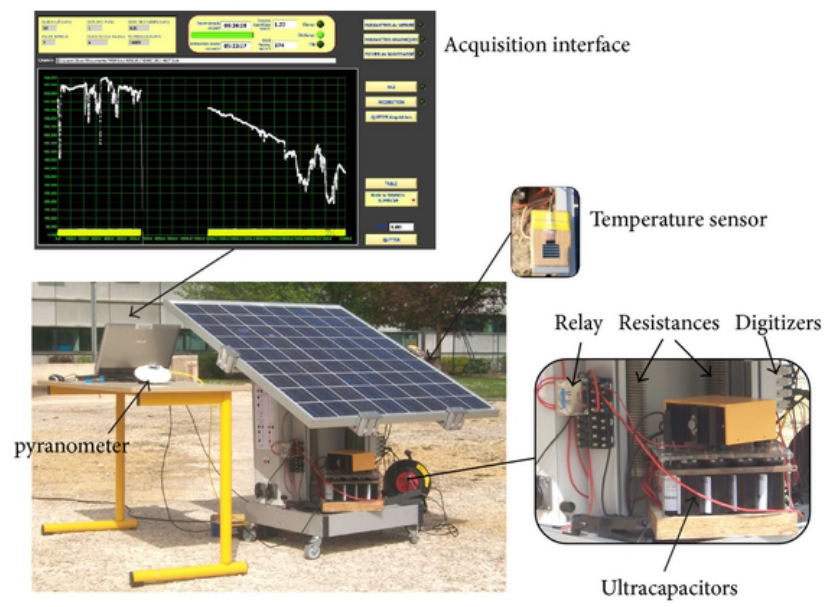

Graphic 2. Instrumented setup of photovoltaic energy storage by supercapacitors Source: (Logerais et al., 2013).

In the above framework blocks, containing shift purposes to restore the force control of an independent force station by considering irregularity in their recreations. The battery has a high energy thickness and the supercapacitor has a powerful thickness, so the blend of both will make an ideal mixture framework. At top force prerequisites, the SC's powerful thickness permits an adequate energy supply inside a brief timeframe. The supercapacitor can rapidly charge after release. Then again, the battery will supply ceaseless capacity to stack for an extensive stretch of time due to its high energy thickness. SC's can likewise lessen battery size in light of the fact that during top hours, the energy will be provided by the supercapacitor, so there is no compelling reason to plan a huge battery to meet pinnacle load prerequisites. Battery life will likewise increment on the grounds that the battery won't go through constant release. Accordingly, the expansion of a supercapacitor will decrease the expense of working and keeping up the framework (Lu et al., 2010).

\subsection{BIODEGRADABLE MATERIALS FOR ELECTROCHEMICAL DOUBLE LAYER CAPACITORS}

Porous carbons have gained popularity in the last decade for the fabrication of SC's. Due to good electrical conductivity, and surface area, carbon based electrodes are widely used. Commonly used carbon based materials are activated carbons AC (Daud \& Ali, 2004; Laine \& Yunes, 1992; Wang et al., 2007), carbon aerogels (Du et al., 2019; Fang \& Binder, 2007; Liu et al., 2007), graphene (Gomibuchi et al., 2006; Ke \& Wang, 2016; Wang \& Yoshio, 2006; 
Guanhua, Zhang et al., 2016; Zhang et al., 2010), carbon nanotubes (Honda et al., 2007; Kaempgen et al., 2009; Katakabe et al., 2005; Liu, 1999; Lu, 2010; Ray et al., 2002), carbon nanofibers, and nano-sized carbons (Eikerling et al., 2005; Honda et al., 2004; Sivakkumar et al., 2007). Due to accessibility, high thermal and chemical stability, sustainability these materials are widely used. However, among all AC's have gained more attention due to its high porosity ratio and surface area (Chen et al., 2017). Table 1 and table 2 summarize the properties of various biodegradable AC's. These properties are responsible for the generation of electrostatic charges.

Table 1. Activated carbon electrodes derived from biowaste performance measurements.

\begin{tabular}{|c|c|c|c|c|}
\hline BIOWASTE & PROCESS & ELECTROLYTE & $\begin{array}{l}\text { CONFIGURATION } \\
\text { OF ELECTRODES }\end{array}$ & REF. \\
\hline $\begin{array}{l}\text { Coconut kernel } \\
\text { Pulp (Milk free) }\end{array}$ & $\mathrm{KOH}$ activation & $1 \mathrm{M} \mathrm{Na}_{2} \mathrm{SO}_{4}$ & \multirow{3}{*}{2 electrodes } & (Kishore et al., 2014) \\
\hline $\begin{array}{l}\text { Corn syrup (High } \\
\text { fructose) }\end{array}$ & $\begin{array}{c}\text { Self-Physical activated } \\
\text { carbon }\end{array}$ & $\mathrm{KOH}$ & & (Cao \& Yang, 2018) \\
\hline $\begin{array}{c}\text { Sugar cane } \\
\text { bagasse }\end{array}$ & $\begin{array}{c}\text { Chemical activation } \\
\text { with } \mathrm{ZnCl} 2\end{array}$ & $1 \mathrm{M} \mathrm{Na}_{2} \mathrm{SO}_{4}$ & & (Rufford et al., 2010) \\
\hline Bamboo & $\begin{array}{l}\text { carbonization and } \\
\mathrm{KOH} \text { activation }\end{array}$ & $3 \mathrm{M} \mathrm{KOH}$ & \multirow{4}{*}{3 electrodes } & (Zhang et al., 2018) \\
\hline Corn stalk core & $\mathrm{KOH}$ activation & & & (Yu et al., 2018) \\
\hline Fish gill & $\begin{array}{l}\text { Carbonization and } \\
\text { termal activation }\end{array}$ & $6 \mathrm{M} \mathrm{KOH}$ & & (Han et al., 2017) \\
\hline Waste tea-leaves & $\begin{array}{c}\text { Carbonisation and } \\
\mathrm{KOH} \text { activation }\end{array}$ & $2 \mathrm{M} \mathrm{KOH}$ & & 145 \\
\hline
\end{tabular}

Source: own elaboration.

Table 2. Porous carbon electrodes derived from biowaste performance measurements.

\begin{tabular}{|c|c|c|c|c|}
\hline BIOWASTE & PROCESS & ELECTROLYTE & $\begin{array}{c}\text { CONFIGURATION } \\
\text { OF ELECTRODES }\end{array}$ & REF. \\
\hline Leaves (Fallen) & $\begin{array}{c}\text { activations of } \\
\left.\text { (KOH and } \mathrm{K}_{2} \mathrm{CO}_{3}\right)\end{array}$ & $6 \mathrm{M} \mathrm{KOH}$ & (Li et al., 2015) \\
\hline $\begin{array}{c}\text { Starch (Porous) } \\
\text { (microsphere) }\end{array}$ & $\begin{array}{c}\text { carbonisation } \\
\text { and } \mathrm{KOH} \text { activation }\end{array}$ & $6 \mathrm{M} \mathrm{KOH}$ & (Du et al., 2013) \\
\hline $\begin{array}{c}\text { Corncob residue } \\
\text { Steam activation } \\
\text { without }\end{array}$ & $\begin{array}{c}\text { pre-carbonization } \\
\text { hydrothermal }\end{array}$ & $6 \mathrm{M} \mathrm{KOH}$ & Qu et al., 2015) \\
\hline $\begin{array}{c}\text { Gelatin } \\
\text { (Nanosheets) }\end{array}$ & $6 \mathrm{M} \mathrm{KOH}$ & & (Fan \& Shen, 2016) \\
\hline
\end{tabular}

Source: own elaboration. 
For sustainable energy generation, the AC production from bio-waste are preponderant phenomena (Benedetti et al., 2018; Guardia et al., 2018; Hill, 2017; Maharjan et al., 2017; Tavasoli et al., 2018; Zhang et al., 2019). AC's are produced from different bio-wastes such as animal, mineral, plant, and vegetables etc. and are used for the fabrication of electrode coating in electrochemical energy generation systems (Gong et al., 2016; Kesavan et al., 2019; Misnon et al., 2015; Na et al., 2018; Nam et al., 2018; Parveen et al., 2019; Sathyamoorthi et al., 2018; Su et al., 2018; Zhang et al., 2019; Zhang et al., 2016) . Carbon-base electrodes are easy to manufacture and have organic electrolytes.

Mi et al. (2012) has developed porous carbon from coconut shells for better performance of SC. Porous Carbon was extracted with the help of pyrolysis and steam activation by a single step thermal treatment process. The volumetric ratio between mesopore and total pore was more than 75 percent. (Jain \& Tripathi, 2014) has synthesized the same carbon from coconut shells, but by using $\mathrm{KOH}$-chemical activation process. The energy and power densities of $88.8 \mathrm{Wh} / \mathrm{kg}$ and $1.63 \mathrm{Kw} / \mathrm{kg}$ were obtained by using these electrodes in combination with polymer electrolyte. Yin $e t$ al. (2016) prepared a multi-tubular but hollow structure of activated carbon from coconut filaments while using $\mathrm{KOH}$-activation. By using this, very high-power density of $8.22 \mathrm{Kw} / \mathrm{kg}$ with a high-energy density of $53 \mathrm{Wh} / \mathrm{kg}$ is obtained. As a result, 3D porous carbon structure exhibits high capacitance among all.

Carbon can be extracted from many agricultural crops and residues for the fabrication of various materials. Wahid et al. (2014) has produced 3D carbon nano channels from bagasse of sugarcane. It has a high surface area and conduction ratio. The pre-processing diagram is in Figure 3.

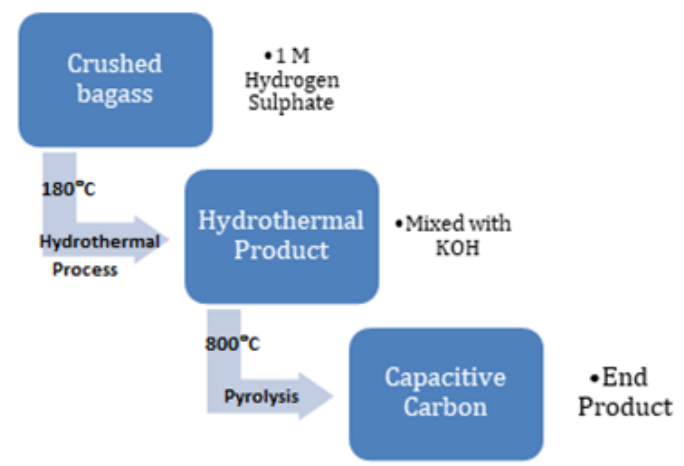

Graphic 3. Carbon extraction from Sugarcane bagass.

Source: own elaboration. 
Qu et al. (2015) focused on the preparation of corncob residue based porous carbon electrodes for SC's. They have adopted a steam activation method for the preparation, and the results have also exhibited well-developed porosity and good conductivity ratios. In addition to this, the researchers have also tested the corncob-based electrodes with two different electrolytes. The power density in aqueous electrolyte was more than organic electrolyte, showing the value of $8276 \mathrm{~W} / \mathrm{kg}$. However, the energy density of $15 \mathrm{Wh} / \mathrm{kg}$ is achieved with organic electrolyte respectively.

Various researches have been conducted for the fabrication of porous carbon electrodes for SC's. A crab shell based multi-hierarchical porous carbon is fabricated by Fu et al. (2019). This structure exhibits great specific capacitance even at low current densities. It was observed that the crab shell-based electrodes showed $94.5 \%$ capacitance preservation over 10,000 cycles. It was concluded that crab shell-based electrodes are a cheap and efficient source of green sustainable energy systems. However, an $84.21 \%$ capacitance retention is achieved from biomass waste cotonnier strobili fibers electrodes.

Ismanto et al. (2010) showed the preparation of activated carbon based electrodes from cassava peel waste. It has a different range of carbon content ranges from $28.7 \%$ to $0.4 \%$, making it a promising candidate for activated carbon precursor. The quantity of carbon present in different bio-waste materials is enlisted in Figure 4. Precursors obtained from porous starch are used for the fabrication of porous carbon microspheres (Du et al., 2013). The samples obtained after stabilization, carbonization and $\mathrm{KOH}$ activation exhibited 98 per cent capacitance retention after thousand cycles. 


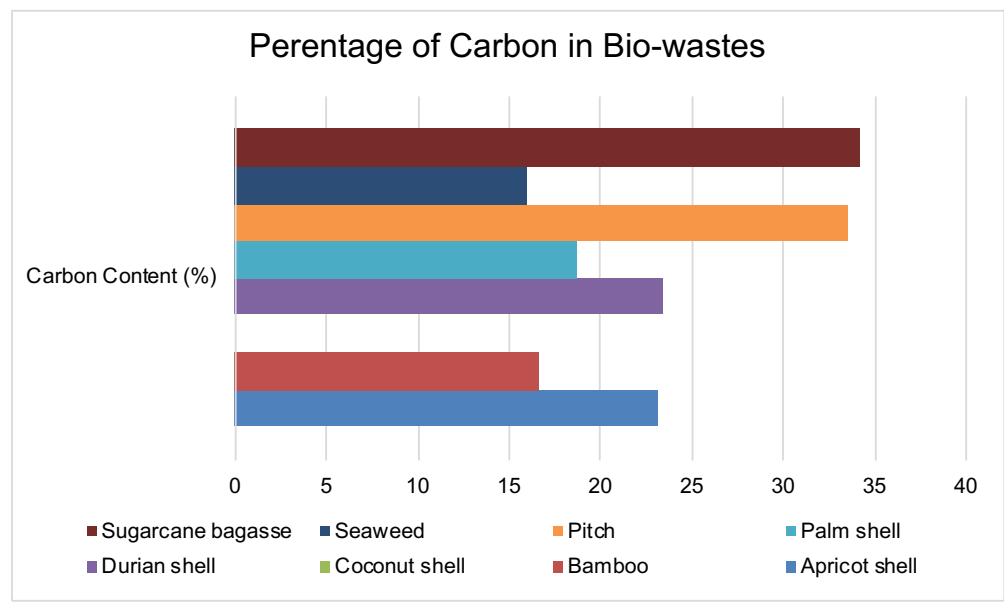

Graphic 4. Corcon Content in different Biowastes.

Source: (Alonso et al., 2006; Azevedo et al., 2007; Chandra et al., 2007; Choy et al., 2005; Daud \& Ali, 2004; Hu \& Srinivasan, 1999; Kumagai et al., 2010; Li et al., 2010; Ray et al., 2002; Raymundo-Piñero et al., 2019; Rufford et al., 2010; Xu et al., 2010).

Soybean based porous carbon is derived from its roots by Guo et al. (2016). The roots were carbonized and processed under nitrogen atmosphere and abbreviated as SRPC-nK, whereas n represents the $\mathrm{KOH} /$ char weight ratio. It was observed that SRPC-4K possesses 98 per cent capacitance retention over 10,000 cycles. The energy and power densities found to be of $100.5 \mathrm{Wh} / \mathrm{kg}$ and $4353 \mathrm{~W} / \mathrm{kg}$, respectively.
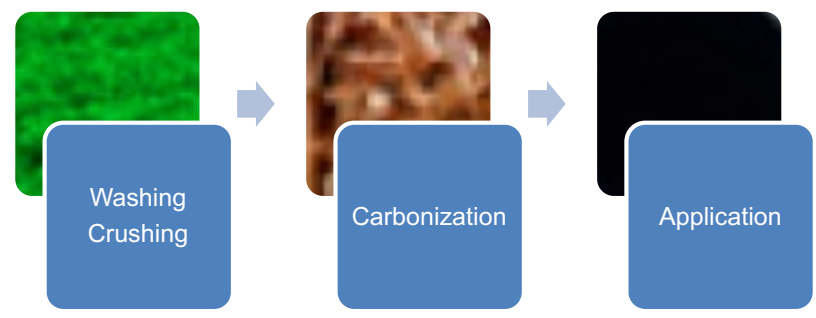

Graphic 5. Carbon activation process.

Source: own elaboration.

Nitrogen-doped activated carbon was fabricated by Ahmed et al. (2018) from orange peels. On the other hand, Yin-Tao et al. (2015) obtained porous active carbon from fallen leaves. The process diagram is shown in Figure 5. The doped carbon electrode exhibited better specific energy and power densities of $23.3 \mathrm{Wh} / \mathrm{kg}$ and $2334.3 \mathrm{~W} / \mathrm{kg}$, while others show greater retention rate. 
Different electrolytes were also developed from various bio sources. A carbonized coconut kernel pulp (milk-free) is developed by Kishore et al. (2014). It was discovered that the surface area is inversely proportional to the temperature. A gel polymer electrolyte from egg white, and SC from its broken shells and rice husks are developed by $\mathrm{Na}$ et al. (2018). The process diagram is illustrated in Figure 10. The resulting product shows a better specific capacitance, flexibility and stable cyclic performance.

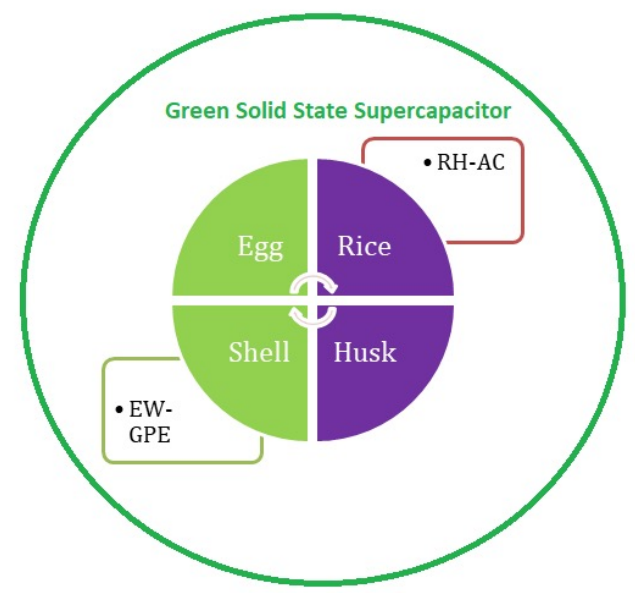

Graphic 6. Fabrication of Green Supercapacitor from egg and rice waste.

Source: own elaboration.

Various bio-waste used for deriving activated carbon that finds application as an electrode material in supercapacitors are listed in Table 3.

Table 3. Physical properties of the activated carbon extracted from biowaste.

\begin{tabular}{|c|c|c|c|c|c|}
\hline BIO-WASTE & $\begin{array}{c}\text { POWER } \\
\text { DENSITY } \\
\text { (W/KG) CYCLES }\end{array}$ & $\begin{array}{c}\text { ENERGY } \\
\text { DENSITY } \\
\text { (WH/KG) }\end{array}$ & $\begin{array}{c}\text { PERCENTAGE } \\
\text { RETENTION (\%) }\end{array}$ & CYCLES & REF. \\
\hline Bamboo & 2250 & 3.3 & 91 & 3000 & (Yang et al., 2014) \\
\hline Celtuce leaves & & 38.5 & 93 & 2000 & (Wang et al., 2012) \\
\hline Coconut shells & & 69 & 85 & 2000 & (Jain \& Tripathi, 2014) \\
\hline Coconut shells & & & 93000 & (Mi et al., 2012) \\
\hline Coconut shell & & & 97.2 & 3000 & (Sun et al., 2017) \\
\hline $\begin{array}{c}\text { Corncob } \\
\text { residue }\end{array}$ & & $5.3-15$ & 82 & 100,000 & (Qu et al., 2015) \\
\hline
\end{tabular}




\begin{tabular}{|c|c|c|c|c|c|}
\hline Cotton (natural) & & 97 & 20,000 & (Cheng et al., 2016) \\
\hline Human hair & 2243 & 29 & $\sim 100$ & $>20,000$ & (Qian et al., 2014) \\
\hline $\begin{array}{c}\text { Ligno-cellulosic } \\
\text { waste fruit } \\
\text { stones }\end{array}$ & 3410 & 13 & 99 & 20,000 & $\begin{array}{c}\text { (Congcong Huang et } \\
\text { al., 2014) }\end{array}$ \\
\hline $\begin{array}{c}\text { Shells of broad } \\
\text { beans }\end{array}$ & & 90 & 3000 & (Xu et al., 2015) \\
\hline
\end{tabular}

Source: own elaboration.

\section{RESULTS AND DISCUSSION}

In this paper, the benefits and drawbacks of Supercapacitors are profoundly evaluated. Two strategies for SC's are utilized for adjusting the voltage of SC's which are proficient and cost effective. SC's are proficient for their quick prominent charging and releasing rate, as well as subsequently can likewise be utilized as a reinforcement power age framework for sustainable power assets. Flywheels are reasonable as they cost less, yet they are gigantic and cannot be utilized wherever more than one elevated level. Lead corrosive Batteries have reliably dangerous issues with respect to charge/release rate and it radically influences the wind turbines, as the drive shaft of rotor edges turn conflicting causing variable voltages for producing power.

Capacitors, then again set aside a lot of effort for charge and delivery rate dissimilar to SC's they don't have longer life consequently they are not naturally cordial. The pitch of wind turbines, can likewise be constrained by utilizing a SC at the more prominent or less point of the edges, which influences the pivot of the sharp edges bringing out lower yield voltage and ending in a failure of the wind turbine. In solar power plants, the conflicting inventory influences the battery life. Batteries are seriously harmed as a result of these yield varieties as they have low force thickness along with a high energy thickness (Younas et al., 2018). Along these lines, utilizing a SC's with a battery, the life of the battery will keep going long and as it won't release constantly and it will diminish the ideal opportunity for upkeep of the framework. 


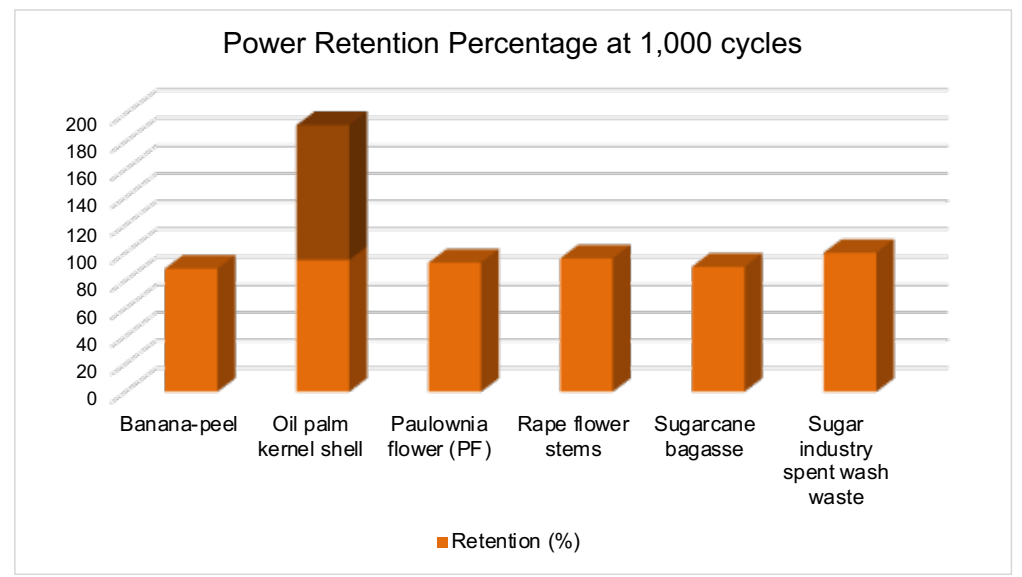

Graphic 7. Power storage capacity of various biodegradable materials at 1,000 cycles (Adopted from Graphic 8 Power density of various biodegradable materials at 1,000 cycles.

Source: (Cao et al., 2017; Chang et al., 2015; Mahto et al., 2017; Misnon et al., 2015; Wahid et al., 2014; Yunya Zhang et al., 2016).

In addition to this, power storage capacity of various biodegradable materials is compared for 1000 cycles in Figure 7. It has been observed that oil plam kernel shows the maximum retention of the charge followed by sugar. However, sugarcane and paulownia occupy the moderate retention. On the other hand, sugar industry spent waste shows the maximum energy density.

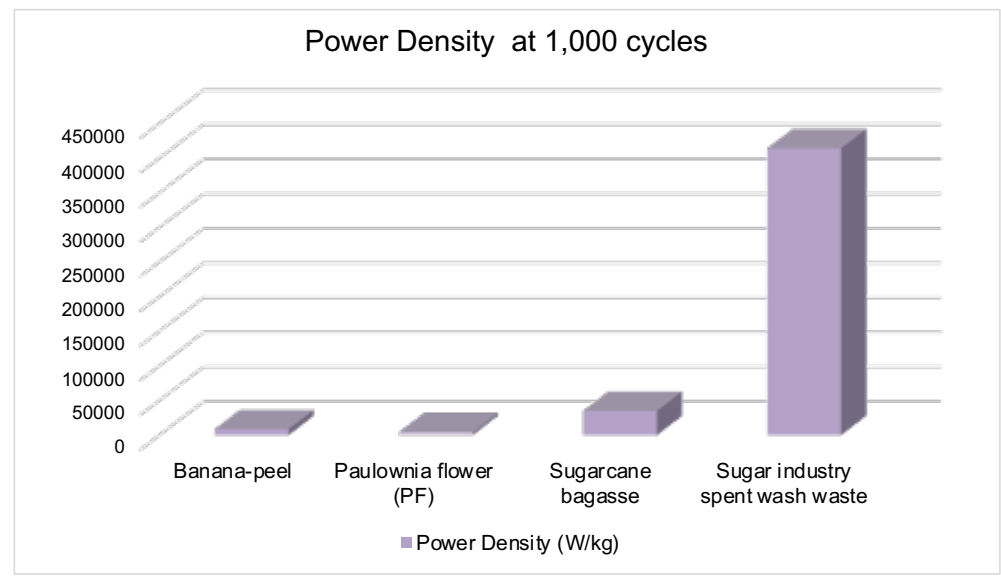

Graphic 9. Power density of various biodegradable materials at 1,000 cycles.

Source: (Cao et al., 2017; Chang et al., 2015; Mahto et al., 2017; Misnon et al., 2015; Wahid et al., 2014; Yunya Zhang et al., 2016).

Figures 9 and 10 shows the power and energy densities and charge retention at 5000 cycles. Figure 9 demonstrate that pea skin has maximum power density, but power retention of 
only 75 per cent as shown in Figure 10. In contrast to this, pea skin exhibits 100 percent retention percentage.

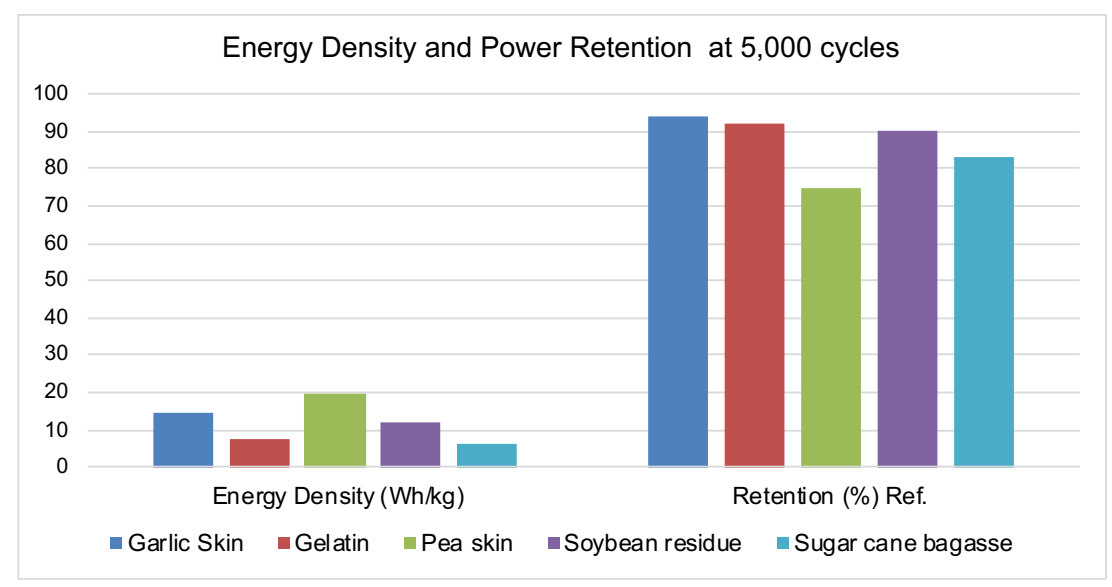

Graphic 10. Power storage capacity of various biodegradable materials at 5,000 cycles.

Source: (Ahmed et al., n.d.; Fan \& Shen, 2016; Ferrero et al., n.d.; Rufford et al., 2010; Q. Zhang et al., 2018).

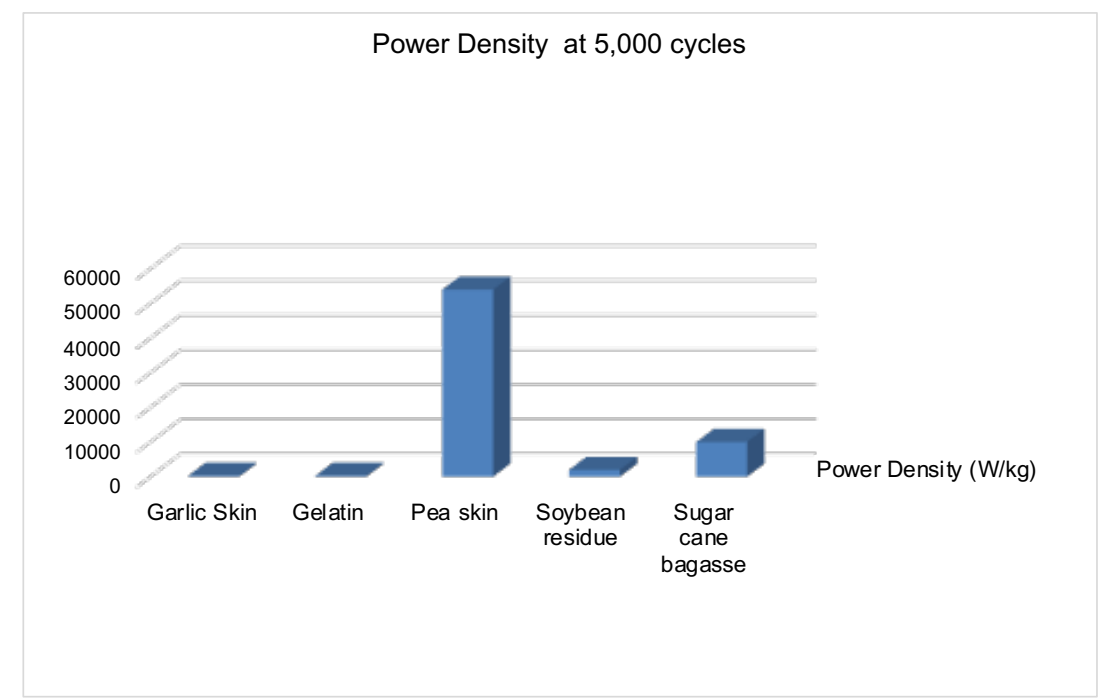

Graphic 11. Power density of various biodegradable materials at ,5000 cycles.

Source: (Ahmed et al., n.d.; Fan \& Shen, 2016; Ferrero et al., n.d.; Rufford et al., 2010; Q. Zhang et al., 2018).

The different bio-waste materials with superior qualities were discovered from further testing. Key performances for bio-waste activated carbon electrodes are shown in Figure 11 for 10,000 cycles. It has been observed that all the materials exhibit more than 90 percent power retention. Among all rice husk sustain maximum charge retention of 97-99 percent. However, soya bean unveils extraordinary properties with $100.5 \mathrm{Wh} / \mathrm{kg}$ and 63,000 W/ 
$\mathrm{kg}$ of energy and power densities, and 98 percent charge retention. The power densities as shown in Graphic 12 are better than the materials discussed in Graphics 8 and 10.

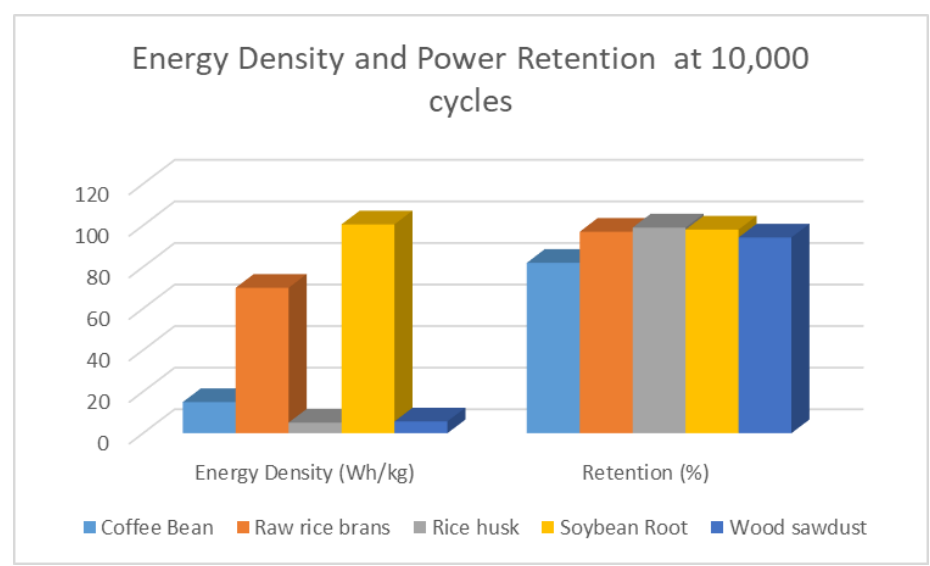

Graphic 12. Power density of various biodegradable materials at 10,000 cycles.

Source: (Guo et al., 2016; Hou et al., 2014; Huang et al., 2013; Huang et al., 2016; Sathyamoorthi et al., 2018; Teo et al., 2016).

\section{CONCLUSIONS}

The above paper concludes that SC's are best for energy storage and for backup power generation in sustainable power resources, but they do have a voltage balancing problem which can be solved by using an active balancing method or passive balancing method. They have fast charge and discharge ratio due to which they are considered over lead acid batteries, flywheels, \& capacitors. Wind turbines, using batteries, store much less energy because of their charge and discharge cycle.

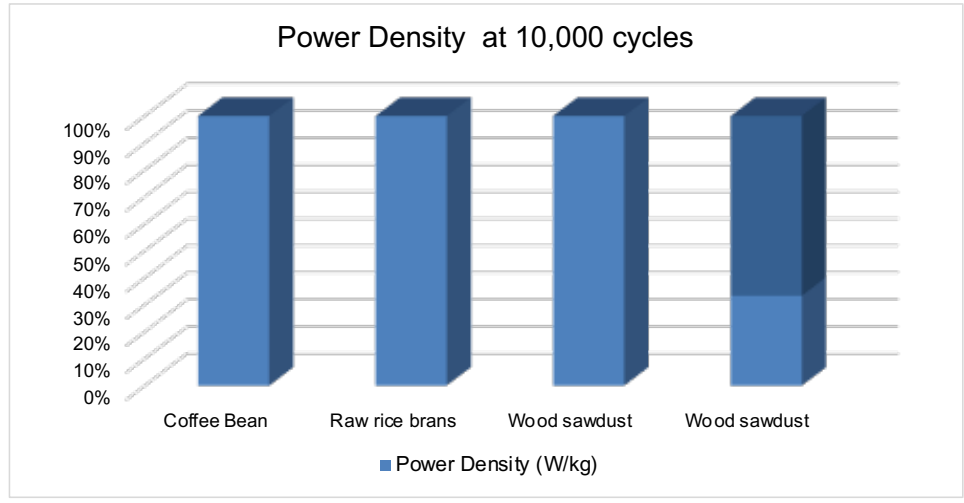

Graphic 13. Power density of various biodegradable materials at 10,000 cycles.

Source: (Guo et al., 2016; Hou et al., 2014; Huang et al., 2013; Huang et al., 2016; Sathyamoorthi et al., 2018; Teo et al., 2016). 
However, on the other hand SC's can store more energy as they charge and release faster and can last longer than batteries. In solar power plants SC's are combined with batteries for better performance, as it increases the battery life, as well as costs less with minimum maintenance. Supercapacitor pitch control system is one of the dominant pitch control systems among other types of pitch control systems as SC's work in both cooler and higher temperature conditions. They not only control the pitch control of sharp edges of every blade separately by featuring it to a certain angle, but also controls the inconsistent voltage as lead acid battery has unsteady voltage causing the turbine blades to rotate abnormally fast or too slow leading into a mishap or a failure. Therefore, SC's efficiently reduces the expense of supplementing parts, maintenance which last for about 10 or more years.

Today, one of the most conspicuous trends is the colossal upsurge in the generation of sustainable renewable energy. There is a widespread worry that this will only lead to a myriad of concerns in the society. In my opinion, sustainable renewable energy has more positive impacts than the negatives. In view of the arguments outlined above, one can conclude that despite having some drawbacks, the benefits of supercapacitors in society are indeed too dire to ignore. The SCis' obtained from bio-products can perform efficiently in extreme conditions and provide a cheap and sustainable solution to the green energy.

\section{REFERENCES}

Ahmed, S., Ahmed, A., \& Rafat, M. (n.d.). Nitrogen doped activated carbon from pea skin for high performance supercapacitor. Mater. Res. Express, $2018(5), 45508$.

Ahmed, S., Rafat, M., \& Ahmed, A. (2018). Nitrogen doped activated carbon derived from orange peel for supercapacitor application. Advances in Natural Sciences: Nanoscience and Nanotechnology, 9(3), 035008. https://doi.org/10.1088/2043-6254/aad5d4

Alonso, A., Ruiz, V., Blanco, G., Santamaría, R., Granda, M., Menéndez, R., \& De Jager, S. G. E. (2006). Activated carbon produced from Sasol-Lurgi gasifier pitch and its application as electrodes in supercapacitors. Carbon, 44(3), 441-446. https://doi.org/10.1016/J.CARBON.2005.09.008 
Azevedo, D. C. S., Araújo, J. C. S., Bastos-Neto, M., Torres, A. E. B., Jaguaribe, E. F., \& Gavalcante, C. L. (2007). Microporous activated carbon prepared from coconut shells using chemical activation with zinc chloride. Microporous and Mesoporous Materials, 100(1-3), 361-364. https://doi.org/10.1016/J.MICROMESO.2006.11.024

Benedetti, V., Patuzzi, F., \& Baratieri, M. (2018). Characterization of char from biomass gasification and its similarities with activated carbon in adsorption applications. Applied Energy, 227, 92-99. https://doi.org/10.1016/J.APENERGY.2017.08.076

Billinton, R. (2005). Impacts of energy storage on power system reliability performance. IEEE Xplorer, 494-497.

Burke, A. (2000). Ultra-capacitors: why, how, and where is the technology. Fournal of Power Sources, 91(9), 37-50. https://doi.org/10.1016/s0378-7753(00)00485-7

Cao, W., \& Yang, F. (2018). Supercapacitors from high fructose corn syrup-derived activated carbons. Materials Today Energy, 9, 406-415. https://doi.org/10.1016/J. MTENER.2018.07.002

Cao, Y., Liu, G., Qian, J., Ghen, Z., \& Chen, F. (2017). Novel 3D porous graphene decorated with $\mathrm{Co} 3 \mathrm{O} 4 / \mathrm{CeO} 2$ for high performance supercapacitor power cell. Journal of Rare Earths, 35(10), 995-1001. https://doi.org/10.1016/S10020721(17)61004-4

Castro-Gutiérrez, J., Celzard, A., \& Fierro, V. (2020). Energy Storage in Supercapacitors: Focus on Tannin-Derived Carbon Electrodes. Frontiers in materials, 7. https://doi.org/10.3389/fmats.2020.00217

Chandra, T. G., Mirna, M. M., Sudaryanto, Y., \& Ismadji, S. (2007). Adsorption of basic dye onto activated carbon prepared from durian shell: Studies of adsorption equilibrium and kinetics. Chemical Engineering fournal, 127(1-3), 121-129. https://doi. org/10.1016/J.CEJ.2006.09.011

Chang, J., Gao, Z., Wang, X., Wu, D., Xu, F., Wang, X., Guo, Y., \& Jiang, K. (2015). Activated porous carbon prepared from paulownia flower for high 
performance supercapacitor electrodes. Electrochimica Acta, 157, 290-298. https:// doi.org/10.1016/J.ELEGTACTA.2014.12.169

Chen, L.-F., Lu, Y. ., Yu, L. ., \& Lou, X. (2017). Designed formation of hollow particlebased nitrogen-doped carbon nanofibers for high-performance supercapacitors. Energy \& Environmental Sciences, 10(8), 1777-1783. https://doi.org/10.1039/ G7EE00488E

Gheng, P., Li, T., Yu, H., Zhi, L., Liu, Z., \& Lei, Z. (2016). Biomass-Derived Carbon Fiber Aerogel as a Binder-Free Electrode for High-Rate Supercapacitors. The Fournal of Physical Chemistry C, 120, 2079-2086.

Choy, K. K. H., Barford, J. P., \& McKay, G. (2005). Production of activated carbon from bamboo scaffolding waste-process design, evaluation and sensitivity analysis. Chemical Engineering Fournal, 109(1-3), 147-165. https://doi.org/10.1016/J. CEJ.2005.02.030

Daud, W. M. A. W., \& Ali, W. S. W. (2004). Comparison on pore development of activated carbon produced from palm shell and coconut shell. Bioresource Technology, 93(1), 63-69. https://doi.org/10.1016/J.BIORTECH.2003.09.015

Du, J., Liu, L., Yu, Y., Zhang, L., Zhang, Y., \& Chen, A. (2019). Synthesis of nitrogen doped graphene aerogels using solid supported strategy for supercapacitor. Materials Chemistry and Physics, 223, 145-151. https://doi.org/10.1016/J. MATCHEMPHYS.2018.10.062

Du, S. hong, Wang, L. qun, Fu, X. ting, Chen, M. ming, \& Wang, C. yang. (2013). Hierarchical porous carbon microspheres derived from porous starch for use in highrate electrochemical double-layer capacitors. Bioresource Technology, 139, 406-409. https://doi.org/10.1016/J.BIORTECH.2013.04.085

Dvorak, P. (2016). Ultracapacitors provide a better way to power pitch systems. Windpower Engineering \& Development. https://www.windpowerengineering.com/ultracapacitors-providebetter-way-power-pitch-systems/. 
Eikerling, M., Kornyshev, A. A., \& Lust, E. (2005). Optimized Structure of Nanoporous Carbon-Based Double-Layer Capacitors. Fournal of The Electrochemical Society, 152(1), E24. https://doi.org/10.1149/1.1825379

Fan, H., \& Shen, W. (2016). Gelatin-Based Microporous Carbon Nanosheets as High Performance Supercapacitor Electrodes. ACS Sustain. Chem. Eng, 4, 1328-1337. https://doi.org/10.1021/acssuschemeng.5b01354

Fang, B., \& Binder, L. (2007). Enhanced surface hydrophobisation for improved performance of carbon aerogel electrochemical capacitor. Electrochimica Acta, 52(24), 6916-6921. https://doi.org/10.1016/J.ELEGTACTA.2007.05.004

Ferrero, G. A., Fuertes, A. B., \& Sevilla, M. (n.d.). From Soybean residue to advanced supercapacitors. Sci.Entific Reports, 2015(5), 16618. https: / /www.nature.com/articles/ srep 16618

Fu,M., Chen, W.,Zhu, X., Yang, B., \&Liu, Q. (2019). Crabshell derived multi-hierarchical carbon materials as a typical recycling of waste for high performance supercapacitors. Carbon, 141, 748-757. https://doi.org/10.1016/J.CARBON.2018.10.034

Gomibuchi, E., Ichikawa, T., Kimura, K., Isobe, S., Nabeta, K., \& Fujii, H. (2006). Electrode properties of a double layer capacitor of nano-structured graphite produced by ball milling under a hydrogen atmosphere. Carbon, 44(5), 983-988. https://doi.org/10.1016/J.GARBON.2005.10.006

Gong, C., Wang, X., Ma, D., Chen, H., Zhang, S., \& Liao, Z. (2016). Microporous carbon from a biological waste-stiff silkworm for capacitive energy storage. Electrochimica Acta, 220,331-339. https://doi.org/10.1016/J.ELECTACTA.2016.10.120

Guardia, L., Suárez, L., Querejeta, N., Pevida, G., \& Genteno, T. A. (2018). Winery wastes as precursors of sustainable porous carbons for environmental applications. Fournal of Cleaner Production, 193, 614-624. https://doi.org/10.1016/J. JCLEPRO.2018.05.085

Guo, N., Li, M. ., Wang, Y. ., Sun, X. ., Wang, F. ., \& Yang, R. (2016). Soybean RootDerived Hierarchical Porous Carbon as Electrode Material for High-Performance 
Supercapacitors in Ionic Liquids. ACS Appl. Mater. Interfaces, 6, 33626-33634. https:// doi.org/10.1021/acsami.6b11162

Haider, A. (2020). Supercapacitors for renewable energy applications. Electronics360., A.https://electronics360.globalspec.com/article/14903/supercapacitors-forrenewable-energy-applications

Han, Y., Shen, N., Zhang, S., Li, D., \& Li, X. (2017). Fish gill-derived activated carbon for supercapacitor application. Fournal of Alloys and Compounds, 694, 636-642. https:// doi.org/10.1016/J.JALLCOM.2016.10.013

Hill,J. M. (2017). Sustainable and/or waste sources for catalysts: Porous carbon development and gasification. Catalysis Today, 285, 204-210. https://doi.org/10.1016/J. CATTOD.2016.12.033

Honda, K., Yoshimura, M., Kawakita, K., Fujishima, A., Sakamoto, Y., Yasui, K., Nishio, N., \& Masuda, H. (2004). Electrochemical Characterization of Carbon Nanotube/Nanohoneycomb Diamond Composite Electrodes for a Hybrid Anode of Li-Ion Battery and Super Capacitor. Fournal of The Electrochemical Society, 151(4), A532. https://doi.org/10.1149/1.1649752

Honda, Y., Haramoto, T., Takeshige, M., Shiozaki, H., Kitamura, T., \& Ishikawa, M. (2007). Aligned MWCNT Sheet Electrodes Prepared by Transfer Methodology Providing High-Power Capacitor Performance. Electrochemical and Solid-State Letters, 10(4), A106. https://doi.org/10.1149/1.2437665

Hou, J., Gao, G., Ma, X., Idrees, F., Xu, B., Hao, X., \& Lin, W. (2014). From Rice Bran to High Energy Density Supercapacitors: A New Route to Control Porous Structure of 3D Carbon. Scientific Reports, 4, 7260.

Hu, Z., \& Srinivasan, M. P. (1999). Preparation of high-surface-area activated carbons from coconut shell. Microporous and Mesoporous Materials, 27(1), 11-18. https://doi. org/10.1016/S1387-1811(98)00183-8 
Huang, G., Sun, T., \& Hulicova-Jurcakova, D. W. (2013). Electrochemical Window of Supercapacitors from Coffee Bean-Derived Phosphorus-Rich Carbons. ChemSusChem, 6, 2330-2339.

Huang, Gongcong, Puziy, A. M., Sun, T., Poddubnaya, O. I., Suárez-García, F., Tascón, J. M. D., \& Hulicova-Jurcakova, D. (2014). Capacitive Behaviours of Phosphorus-Rich Carbons Derived from Lignocelluloses. Electrochimica Acta, 137, 219-227. https://doi.org/10.1016/J.ELECTACTA.2014.05.101

Huang, Y., Peng, L., Liu, Y., Zhao, G., Chen, J. Y., \& Yu, G. (2016). Biobased Nano Porous Active Carbon Fibers for High-Performance Supercapacitors. ACS Appl. Mater. Interfaces, 8, 15205-15215.

Ismanto, A. E., Wang, S., Soetaredjo, F. E., \& Ismadji, S. (2010). Preparation of capacitor's electrode from cassava peel waste. Bioresource Technology, 101(10), 35343540. https://doi.org/10.1016/J.BIORTECH.2009.12.123

Jain, A., \& Tripathi, S. K. (2014). Fabrication and characterization of energy storing supercapacitor devices using coconut shell based activated charcoal electrode. Materials Science and Engineering: B, 183(1), 54-60. https://doi.org/10.1016/J. MSEB.2013.12.004

Kaempgen, M., Chan, G. K., Ma, J., Gui, Y., \& Gruner, G. (2009). Printable Thin Film Supercapacitors Using Single-Walled Carbon Nanotubes. Nano Letters, 9, 1872-1876.

Katakabe, T., Kaneko, T., Watanabe, M., Fukushima, T., \& Aida, T. (2005). Electric Double-Layer Capacitors Using "Bucky Gels" Consisting of an Ionic Liquid and Carbon Nanotubes. Fournal of The Electrochemical Society, 152(10), A1913. https://doi. org/10.1149/1.2001187

Ke, Q., \& Wang, J. (2016). Graphene-based materials for supercapacitor electrodes - A review. Fournal of Materiomics, 2(1), 37-54. https://doi.org/10.1016/J. JMAT.2016.01.001

Kesavan, T., Partheeban, T., Vivekanantha, M., Kundu, M., Maduraiveeran, G., \& Sasidharan, M. (2019). Hierarchical nanoporous activated carbon as 
potential electrode materials for high performance electrochemical supercapacitor. Microporous and Mesoporous Materials, 274, 236-244. https://doi.org/10.1016/J. MICROMESO.2018.08.006

Kishore, B. ., Shanmughasundaram, D. ., Penki, T. R. ., \& Munichandraiah, N. (2014). Coconut kernel-derived activated Electrochem., carbon as electrode material for electrical double-layer capacitors. Fournal of Applied Electrochemistry, 44, 903-916. https://link.springer.com/article/10.1007\%2Fs 10800-014-0708-9

Kumagai, S., Ishizawa, H., \& Toida, Y. (2010). Influence of solvent type on dibenzothiophene adsorption onto activated carbon fiber and granular coconutshell activated carbon. Fuel, 89(2), 365-371. https://doi.org/10.1016/J. FUEL.2009.08.013

Laine, J., \& Yunes, S. (1992). Effect of the preparation method on the pore size distribution of activated carbon from coconut shell. Carbon, 30(4), 601-604. https:// doi.org/10.1016/0008-6223(92)90178-Y

Li, X., Han, G., Chen, X., \& Shi, G. (2010). Preparation and performance of straw based activated carbon for supercapacitor in non-aqueous electrolytes. Microporous and Mesoporous Materials, 131(1-3), 303-309. https://doi.org/10.1016/J. MICROMESO.2010.01.007

Li, Y. T., Pi, Y. T., Lu, L. M., Xu, S. H., \& Ren, T. Z. (2015). Hierarchical porous active carbon from fallen leaves by synergy of $\mathrm{K} 2 \mathrm{CO} 3$ and their supercapacitor performance. Fournal of Power Sources, 299, 519-528. https://doi.org/10.1016/J. JPOWSOUR.2015.09.039

Liu, G. (1999). Electrochemical Characterization of Films of Single-Walled Carbon Nanotubes and Their Possible Application in Supercapacitors. Electrochemical and Solid-State Letters, 2(1 1), 577. https://doi.org/10.1149/1.1390910

Liu, X. M., Zhang, R., Zhan, L., Long, D. H., Qiao, W. M., Yang, J. He, \& Ling, L. C. (2007). Impedance of carbon aerogel/activated carbon composites as electrodes 
of electrochemical capacitors in aprotic electrolyte. New Carbon Materials, 22(2), 153158. https://doi.org/10.1016/S1872-5805(07)60015-8

Logerais, P.-O., Riou, O., Ansoumane, M., \& Durastanti, J. F. (2013). Study of Photovoltaic Energy Storage by Supercapacitors through Both Experimental and Modelling Approaches. Fournal of Solar Energy, 2013, Article ID 659014. https://doi. org/10.1155/2013/659014

Lu, D., Fakham, H., Zhou, T., \& François, B. (2010). Application of Petri nets for the energy management of a photovoltaic based power station including storage units. Renewable Energy, 35(6), 1117-1124. https://doi.org/10.1016/j.renene.2009.12.017

Lu, W. (2010). Carbon Nanotube Supercapacitors. (J. M. . E. . I. R. C. Marulanda (Ed.)).

Maharjan, M., Bhattarai, A., Ulaganathan, M., Wai, N., Oo, M. O., Wang, J. Y., \& Lim, T. M. (2017). High surface area bio-waste based carbon as a superior electrode for vanadium redox flow battery. Fournal of Power Sources, 362, 50-56. https://doi. org/10.1016/J.JPOWSOUR.2017.07.020

Mahto, A., Gupta, R., Ghara, K. K., Srivastava, D. N., Maiti, P., Kalpana, D., Zavala-Revira, P., Meena, R., \& Nataraj, S. K. (2017). Development of highperformance supercapacitor electrode derived from sugar industry spent wash waste. Journal of Hazardous Materials, 340, 189-201. https://doi.org/10.1016/J. JHAZMAT.2017.06.048

Mi, J. ., Wang, X. R. ., Fan, R. J. ., Qu, W. H. ., \& Li, W. C. (2012). Coconut-shellbased porous carbons with a tunable micro/mesopore ratio for high-performance supercapacitors. Energy Fuels, 26, 5321-5329.

Misnon, I. I., Zain, N. K. M., Aziz, R. A., Vidyadharan, B., \& Jose, R. (2015). Electrochemical properties of carbon from oil palm kernel shell for high performance supercapacitors. Electrochimica Acta, 174(1), 78-86. https://doi.org/10.1016/J. ELECTACTA.2015.05.163

Na, R., Wang, X., Lu, N., Huo, G., Lin, H., \& Wang, G. (2018). Novel egg white gel polymer electrolyte and a green solid-state supercapacitor derived from the 
egg and rice waste. Electrochimica Acta, 274, 316-325. https://doi.org/10.1016/J. ELEGTACTA.2018.04.127

Nam, H., Ghoi, W., Genuino, D. A., \& Capareda, S. C. (2018). Development of rice straw activated carbon and its utilizations. Fournal of Environmental Chemical Engineering, 6(4), 5221-5229. https://doi.org/10.1016/J.JECE.2018.07.045

Parveen, N., Al-Jaafari, A. I., \& Han, J. I. (2019). Robust cyclic stability and high-rate asymmetric supercapacitor based on orange peel-derived nitrogen-doped porous carbon and intercrossed interlinked urchin-like NiCo2O4@3DNF framework. ElectrochimicaActa,293,84-96.https://doi.org/10.1016/J.ELEGTACTA.2018.08.157

Pikkarainen, J. (n.d.). Wind Turbine Pitch Control - Ultra capacitors Solving Unreliability \& Unpredictability with the Lowest TCO. 2021. https://www.skeletontech.com/ skeleton-blog/wind-turbine-pitch-control-ultracapacitors-solving-unreliabilityunpredictability

Qian, W., Sun, F., Xu, Y., Qiu, L., Liu, G., Wang, S., \& Yan, F. (2014). Human hairderived carbon flakes for electrochemical supercapacitors. Energy \& Environmental Sciences, 7(1), 379-386.

Qu, W. H., Xu, Y. Y., Lu, A. H., Zhang, X. Q., \& Li, W. C. (2015). Converting biowaste corncob residue into high value added porous carbon for supercapacitor electrodes. Bioresource Technology, 189, 285-291. https://doi.org/10.1016/J. BIORTEGH.2015.04.005

Ray H, B., Anvar A, Z., \& Walt A., de H. (2002). Carbon Nanotubes--the Route Toward Applications. Science, 297(5582), 787-792.

Raymundo-Piñero, E., Cadek, M., \& Béguin, F. (2019). Tuning Carbon Materials for Supercapacitors by Direct Pyrolysis of Seaweeds. Advance Materials, 19, 1032-1039.

Rufford, T. E., Hulicova-Jurcakova, D., Khosla, K., Zhu, Z., \& Lu, G. Q. (2010). Microstructure and electrochemical double-layer capacitance of carbon electrodes prepared by zinc chloride activation of sugar cane bagasse. Fournal of Power Sources, 195(3), 912-918. https://doi.org/10.1016/J.JPOWSOUR.2009.08.048 
Sathyamoorthi, S., Phattharasupakun, N., \& Sawangphruk, M. (2018). Environmentally benign non-fluoro deep eutectic solvent and free-standing rice husk-derived bio-carbon based high-temperature supercapacitors. Electrochimica Acta, 286, 148-157. https://doi.org/10.1016/J.ELEGTACTA.2018.08.027

Schainker, R. B. (2004). Executive overview: energy storage options for a sustainable energy future. Smart Grid and Renewable Energy, 2309-2314.

Simon, P., Gogotsi, Y., \& Dunn, B. (2014). Where Do Batteries End and Supercapacitors Begin? https://www.science.org/doi/abs/10.1126/science.1249625.

Sivakkumar, S. R., Ko, J. M., Kim, D. Y., Kim, B. G., \& Wallace, G. G. (2007). Performance evaluation of CNT/polypyrrole/MnO2 composite electrodes for electrochemical capacitors. Electrochimica Acta, 52(25), 7377-7385. https://doi. org/10.1016/J.ELEGTACTA.2007.06.023

Su, X. L., Li, S. H., Jiang, S., Peng, Z. K., Guan, X. X., \& Zheng, X. G. (2018). Superior capacitive behavior of porous activated carbon tubes derived from biomass waste-cotonier strobili fibers. Advanced Powder Technology, 29(9), 2097-2107. https:// doi.org/10.1016/J.APT.2018.05.018

Sun, K., Leng, G. Y., Jiang, J. G., Bu, Q., Lin, G. F., Lu, X. G., \& Zhu, G. Z. (2017). Microporous activated carbons from coconut shells produced by self-activation using the pyrolysis gases produced from them, that have an excellent electric double layer performance. New Carbon Materials, 32(5), 451-459. https://doi.org/10.1016/S18725805(17)60134-3

Supercapacitors: Making Renewable Energy Viable. (2011). Science 2.0. https:// www.science20.com/news_articles/supercapacitors_making_renewable_energy_ viable-9201 1

Tavasoli, A., Aslan, M., Salimi, M., Balou, S., Pirbazari, S. M., Hashemi, H., \& Kohansal, K. (2018). Influence of the blend nickel/porous hydrothermal carbon and cattle manure hydrochar catalyst on the hydrothermal gasification of cattle 
manure for H2 production. Energy Conversion and Management, 173, 15-28. https:// doi.org/10.1016/J.ENCONMAN.2018.07.061

Teo, E. Y. L., Muniandy, L., Ng, E. P., Adam, F., Mohamed, A. R., Jose, R., \& Chong, K. F. (2016). High surface area activated carbon from rice husk as a high performance supercapacitor electrode. Electrochimica Acta, 192, 110-119. https:/ / doi. org/10.1016/J.ELECTACTA.2016.01.140

Wahid, M., Puthusseri, D., Phase, D., \& Ogale, S. (2014). Enhanced capacitance retention in a supercapacitor made of carbon from sugarcane bagasse by hydrothermal pretreatment. Energy Fuels, 28, 4233-4240. https://doi.org/10.1021/ef500342d

Wang, H., \& Yoshio, M. (2006). Graphite, a suitable positive electrode material for highenergy electrochemical capacitors. Electrochemistry Communications, 8(9), 1481-1486. https://doi.org/10.1016/J.ELECOM.2006.07.016

Wang, H., Yoshio, M., Thapa, A. K., \& Nakamura, H. (2007). From symmetric AC/AC to asymmetric AC/graphite, a progress in electrochemical capacitors. Fournal of Power Sources, 169(2), 375-380. https://doi.org/10.1016/J.JPOWSOUR.2007.02.088

Wang, R., Wang, P., Yan, X., Lang, J., Peng, C., \& Xue, Q. (2012). Promising Porous Carbon Derived from Celtuce Leaves with Outstanding Supercapacitance and CO2 Capture Performance. 4, 5800-5806. https://doi.org/10.1021/am302077c

Werkstetter, S. (2015). Ultracapacitor Usage in Wind Turbine Pitch Control Systems | AltEnergyMag. Altenergymag.com. https://www.altenergymag.com/article/2015/06/ultracapacitorusage-in-wind-turbine-pitch-control-systems/20392

Xu, B., Ghen, Y., Wei, G., Cao, G., Zhang, H., \& Yang, Y. (2010). Activated carbon with high capacitance prepared by $\mathrm{NaOH}$ activation for supercapacitors. Materials Chemistry and Physics, 124(1), 504-509. https://doi.org/10.1016/J. MATCHEMPHYS.2010.07.002

Xu, G., Han, J., Ding, B., Nie, P., Pan, J., Dou, H., Li, H., \& Zhang, X. (2015). Biomass-derived porous carbon materials with sulfur and nitrogen dual-doping for energy storage. Green Chemistry, 17, 1668-1674. 
Yang, C. S., Jang, Y. S., \& Jeong, H. K. (2014). Bamboo-based activated carbon for supercapacitor applications. Current Applied Physics, 14(12), 1616-1620. https://doi. org/10.1016/J.CAP.2014.09.021

Yin, L., Chen, Y., Li, D., Zhao, X., Hou, B., \& Cao, B. (2016). 3-Dimensional hierarchical porous activated carbon derived from coconut fibers with high-rate performance for symmetric supercapacitors. Materials $\mathcal{E}$ Design, 111, 44-50. https:// doi.org/10.1016/J.MATDES.2016.08.070

Younas, T., Bano, N., Khalid, M. A., Ahmed, A., \& Noman, M. (2018). An Experimental Study of Modelling and Fabrication of an Autonomous Solar Parabolic Trough Collector. International Conference on Computing, Electronic and Electrical Engineering (ICE Cube) -IEEE Xplorer, 12-13. https://doi.org/10.1109/icecube.2018.8610980

Younas, T., Rasheed, H., Rehman, M. M., \& Ramzan, R. (2018). Solar Energy as Expedient Alternatives for Nuclear Energy. E3S Web of Conferences EDP Sciences, 51, 02001-02004. https://doi.org/10.1051/e3sconf/20185102001

Yu, K., Zhu, H., Qi, H., \& Liang, G. (2018). High surface area carbon materials derived from corn stalk core as electrode for supercapacitor. Diamond and Related Materials, 88, 18-22. https://doi.org/10.1016/J.DIAMOND.2018.06.018

Zhang, Guanhua, Song, Y., Zhang, H., Xu, J., Duan, H., \& Liu, J. (2016). Radially Aligned Porous Carbon Nanotube Arrays on Carbon Fibers: A Hierarchical 3D Carbon Nanostructure for High-Performance Capacitive Energy Storage. Advance Functional Materials, 26, 3012-3020.

Zhang, Guoxiong, Ghen, Y., Ghen, Y., \& Guo, H. (2018). Activated biomass carbon made from bamboo as electrode material for supercapacitors. Materials Research Bulletin, 102, 391-398. https://doi.org/10.1016/J.MATERRESBULL.2018.03.006

Zhang, L., Li, H., A Rui, Z., \& Zhao A, X. S. (2010). Graphene-based materials as supercapacitor electrodes. Fournal of Materials Chemistry, 29, 5983-5992. 
Zhang, Q., Han, K., Li, S., Li, M., Li, J., \& Ren, K. (2018). Synthesis of garlic skinderived 3D hierarchical porous carbon for high-performance supercapacitors. IOPNanoscale, 10, 2427-2437.

Zhang, Ying, Song, X., Xu, Y., Shen, H., Kong, X., \& Xu, H. (2019). Utilization of wheat bran for producing activated carbon with high specific surface area via $\mathrm{NaOH}$ activation using industrial furnace. Fournal of Cleaner Production, 210, 366-375. https://doi.org/10.1016/J.JCLEPRO.2018.11.041

Zhang, Y., Gao, Z., Song, N., \& Li, X. (2016). High-performance supercapacitors and batteries derived from activated banana-peel with porous structures. Electrochimica Acta, 222, 1257-1266. https://doi.org/10.1016/J.ELECTACTA.2016.11.099 
